\title{
THE CREATION OF A CONTAGIOUS H5N1 INFLUENZA VIRUS: IMPLICATIONS FOR THE EDUCATION OF LIFE SCIENTISTS
}

\author{
Tatyana NOVOSSIOLOVA, Masamichi MINEHATA, Malcolm DANDO \\ Bradford Disarmament Research Centre Division of Peace Studies School of Social and \\ International Studies University of Bradford UK
}

The paper contends that the ongoing controversy surrounding the creation of a contagious H5N1 influenza virus has already exposed the severe limitations of the possibility of preventing the hostile misuse of the life sciences by dint of oversight of proposals and publications. It further argues that in order to prevent the potential wholesale militarisation of the life sciences, it is essential that life scientists become aware of their responsibilities within the context of the Biological and Toxin Weapons Convention (BTWC) and actively contribute their expertise to strengthening the biological weapons non-proliferation regime.

Key words: H5N1, life sciences, oversight, education, BTWC, bioterrorism.

"...The race is on for scientists to Gind out as much as they can about H5N1 and detect any mutations that make it a human-to-human virus as soon as possible. At least then they will know exactly what it is they are Gighting.... In many ways, it [influenza virus] is the perfect form of bio-terrorism - simple yet devastating."

Revill J. (2005) Everything you need to know about Bird Flu and what you can do to prepare for it. (page 27) Rodale, London.

B y April 2012 there have been 602 laboratory-confirmed cases of human infection with highly pathogenic avian influenza H5N1 virus [1]. 355 of these people died, but sustained human-to-human transmission had not been demonstrated. Then in late 2011 it was reported that life scientists in The Netherlands and the United States had shown how the H5N1 virus could be made contagious through the air in mammals. This provoked a wide-ranging debate about whether, and how, the work should be published, or, indeed, whether it should have been carried out in the first place.

Whilst that debate has, at the time of writing this paper, not yet finished, it is our contention that it has already exposed the severe limitations of the approach to the responsibilities of life scientists which has dominated discussions of the hostile misuse of the life sciences since 9/11 and the anthrax letter attacks in the United States. This approach, which is typified by the Fink Report [2] on Biotechnology Research in an Age of Terrorism of 2004, suggests that as terrorists might misuse advanced life science research, such dual-use dangers can be prevented by restrictions (oversight) of project proposals and publications.

This paper begins with examination of the debate provoked by the attempt to publish the papers on contagious $\mathrm{H} 5 \mathrm{~N} 1$ and argues that there are good reasons why the bioterror/dualuse approach can only be relevant to a small part of the problem of containing the potential hostile misuse of the results of the ongoing revolution in the life sciences. That leads on to our suggestion that the real problem is that biotechnology, like other scientific and technological revolutions in the past, may, as pointed out by Professor Mathew Meselson [3] in 2000 , be "intensively exploited, not only for peaceful purposes but also for hostile ones." In short, bioterrorism and the exploitation of the results of advances in the life sciences by terrorists has to be seen in the wider framework of the potential wholesale militarization of the life sciences, and a much wider set of responsibilities than oversight of projects and publications is required of life scientists if their work is to be properly protected from misuse.

For this reason, the paper then briefly introduces the history of offensive State-level biological weapons programmes during the last century and the gradual development of the prohibition regime centred on the 1975 Biological and Toxin Weapons Convention (BTWC). It is argued that life scientists' responsibilities have to be seen within this wider framework and the 'web of preventive policies' centred on the BTWC, and that the issue of dual-use and bioterrorism is better understood as part of this wider framework.

This then leads to an examination of the discussions amongst State Parties to the BTWC about 
awareness-raising and education of life scientists during this century. The paper ends with our own reflections on what needs to be covered in the education of life scientists for them to be able to actively engage in effectively protecting their benignly-intended work from misuse and an illustration of what might be done now to assist State Parties in their deliberations on the implications of advances in the life sciences through to the Eighth Five-Year Review Conference of the BTWC in 2016.

\section{The Contagious Lethal H5N1 Debate}

The committee chaired by Gerald Fink produced its report on Biotechnology Research in an Age of Terrorism in good part because of the increasing concerns about terrorism. As the report noted [4] "Biotechnolgy represents a 'dual-use' dilemma in which the same technologies can be used legitimately for human betterment and misused for terrorism". Two points that are often forgotten are, first, that the committee viewed bioterrorism as only part of [5] "a wide spectrum of potentially dangerous activities" posed "by hostile individuals and nations", and, secondly, that the committee's first recommendation read as follows [6]:

"We recommend that national and international professional societies and related organisations and institutions create programs to educate scientists about the nature of the dual-use dilemma in biotechnology and their responsibilities to mitigate its risks."

We will return to both of these points later.

However, the Fink Committee is chiefly remembered for two quite different points. First, it suggested that there were at least seven classes of (mainly microbiological) research that were of sufficient concern to warrant oversight prior to being undertaken or published in full after being carried out. These experiments included those which [7]:

" 1 . Would demonstrate how to render a vaccine ineffective...

2. Would confer resistance to therapeutically useful antibiotics or antiviral agents...

3. Would enhance the virulence of a pathogen or render a nonpathogen virulent...

4. Would increase the transmissibility of a pathogen...

5. Would alter the host range of a pathogen...

6 . Would enable the evasion of diagnostic/detection modalities...

7. Would enable the weaponization of a biological agent or toxin...”
The committee went on to note, directly after listing these categories, that "Over time...it will be necessary to expand the experiments of concern to cover a significantly wider range of potential threats" and this point was fully endorsed by the subsequent Lemon-Relman Report [8] of the US National Academies.

Secondly, the Fink Committee recommended the setting up of a national committee to [9] "provide advice, guidance, and leadership for the system of review and oversight we are proposing". This in turn led to the establishment of the National Science Advisory Board for Biosecurity (NSABB) which has actively endeavoured to fulfil this remit. One of the Board's first endeavours, in 2005 , concerned the publication of the sequencing and synthesis of deadly Spanish Influenza virus. They approved publication, but it should be noted that the then editor of Science is on record [10] as stating "So would I...have published the paper even if the NSABB have voted otherwise? Absolutely..."

So it is against that background of widespread ignorance of, and opposition to, biosecurity considerations that current concerns about H5N1 have to be understood. And this is so even though in the years after $9 / 11$ editors of leading science journal agreed to institute a biosecurity review of publications of concern [11], grant giving organisations began to ask applicants if they had taken biosecurity issues into account [12], the InterAcademy Panel published the principles of a code of conduct related to biosecurity [13], and The Netherlands Academy of Science published a specific biosecurity code of conduct [14]. Moreover, The Netherlands code had the text of the BTWC as its first appendix, and the lead scientist in the Dutch study on $\mathrm{H} 5 \mathrm{~N} 1$ was part of the group that produced the code.

Of course, it is not possible at this stage to give a full account of what happened in these $\mathrm{H} 5 \mathrm{~N} 1$ projects and attempted publications, but certain facts are already known and allow for some conclusions to be drawn as to the utility of the oversight system. The two studies first became widely known when an article appeared in Science in November 2011 [15]. From this article it was clear that both projects, at the Erasmus Medical Centre in Rotterdam, the Netherlands, and at the University of Wisconsin, Madison had been funded and approved for publication by the US National Institutes of Health before they were submitted to Science (and Nature) when the NSABB became involved. The Guardian quoted Paul Keim, chair of NSABB, as stating [16] "If this virus were to 
escape by error or terror, we must ask whether it would cause a pandemic" and adding that:

"The probability is unknown, but it is not zero. There are many scenarios to consider, ranging from mad lone scientists, desperate despots and members of millennial doomsday cults, to nation states wanting mutually assured destruction options, bioterrorists or a single person's random acts of craziness."

According to the deputy editor of Science about 1, 000 scientists were already familiar with the details of the Dutch study [17]. This revelation is curious, not least because the Netherlands group seems to have deviated from the national Code of Conduct on Biosecurity and its provisions on 'Research and Publication Policy', according to which scientists should [18]: "Screen for possible dual-use aspects during the application and assessment procedure and during the execution of research projects."

Still, it can reasonably be argued that there has been a degree of 'over-hype' in regard to the capabilities of terrorists to replicate papers that report the results of cutting-edge research.

For example, one of the original experiments that caused concern early in this century was the chemical synthesis of the polio virus [19]. However, on closer examination it was found that crucial tacit knowledge, which would not have been available from the published paper, was required to replicate the synthesis [20]. The team at the University of Wisconsin-Madison [21]:

"...created a chimeric virus with the haemagglutinin protein from $\mathrm{H} 5 \mathrm{~N} 1$ and the genes from the 2009 pandemic strain of H1N1. It was an artificial version of the same process though which wild viruses shuffle their genes, known as reassortment..."

The mutant virus spread easily among ferrets, but did not retain its virulence. The work in The Netherlands caused more concern. The virus genome was first altered so that the mutant strain could easily attach to mammalian nose and tracheal cells. However, the virus could not spread between individuals through the air. To overcome the deficiency, the researchers then exposed ferrets to the strain and used nasal fluids from the already sickened animals to infect others:

"...After 10 rounds, the virus could spread through the air to infect ferrets in neighbouring cages. The genome of the airborne strain differed from the original one by just Give mutations..."
Moreover when this new mutant virus was implanted physically into the trachea or nasal passages of ferrets, the animals died. Ferrets are the surrogate organisms for such work on mammals and the use of passage through a series of animals is well known as a standard method of increasing the virulence of a pathogen. According to Michael Imperiale, a professor of microbiology and member of the NSABB, the technology of making influenza viruses from DNA clones is widely available and "while not simple, is not beyond someone with basic knowledge of molecular and cell culture techniques" [22]. This in turn implies that tacit knowledge requirements are unlikely to be as high if an attempt were made to replicate that part of the work. Moreover, the reason that so many people were thought to have knowledge of the Netherlands work was because it was presented at an international conference on Influenza research in Malta prior to being submitted for publication [23].

Throughout the period of dominance of the dual-use/bioterrorism framework of understanding the threat it has been suggested that oversight of projects and publications should be based on an assessment of the risks as against the benefits of a research project or publication. Hence the researchers who carried out these H5N1 studies have argued that their work could help in detecting the occurrence of a dangerous new virus, like the ones they created, in nature, and in the development of vaccines against such a new virus. Some scientists, however, have dismissed such claims as 'hollow' emphasising that the "risk/benefit ratio is essentially infinite - high risk relative to zero or nearzero benefit" [24], As an editorial in Nature has underscored [25]:

"In practice, the immediate benefits are minimal. Surveillance of influenza in animals is slow and patchy at best, and follow-up sequencing of samples more so.

And the mutations that we know about are likely to be outnumbered by those about which we are still ignorant...”

And, further, that:

"...Current techniques can produce vaccines only six months after a pandemic emerges. Doing so faster and in much larger quantities is the most urgent publichealth priority when it comes to planning for the next pandemic. The mutant-Glu studies contribute little to this goal..."

The calling into question of whether the $\mathrm{H} 5 \mathrm{~N} 1$ research has any benefits to society is more serious, perhaps, than many realise because the 
BTWC clearly bans work that has no justification for peaceful purposes. Article I of the Convention states that [26]:

"Each State Party to this Convention undertakes never in any circumstances to develop, produce, stockpile or otherwise acquire or retain:

1. Microbial or other agents, or toxins whatever their origin or method of production, of types and in quantities that have no justification for prophylactic, protective or other peaceful purposes..."

Now it may be objected that the Convention does not prohibit research, but that is to ignore what State Parties have agreed at each Review Conference in regard to Article I since 1991. As the Final Document of the Seventh Review Conference of the BTWC in December 2011 stated [27]:

"The Conference notes that experimentation involving open air release of pathogens or toxins harmful to humans, animals and plants that have no justification for prophylactic, protective or other peaceful purposes is inconsistent with the undertakings contained in Article I."

There certainly cannot be any doubt that some of these H5N1 experiments involved demonstrating that the deadly virus was contagious through the open air from infected ferrets to uninfected ferrets. The Netherlands group made it clear that this was their objective when they pointed out that [28] "Our research program aimed to test whether A/H5N1 virus could acquire the ability to spread in aerosols in mammals, following similar genetic changes as those identified in previous pandemic viruses..." Likewise, the primary goals of the US team were to "evaluate the pandemic potential of H5N1 viruses" and "identify the molecular features required for adaptation of avian $\mathrm{H} 5 \mathrm{~N} 1$ viruses in humans" [29].

It could, of course, be objected that what State Parties referred to in their common understanding was large scale open-air tests. However, as making an influenza virus contagious through the air is effectively to weaponise it there must be reservation about such an objection. Furthermore, Article III of the BTWC states that [30]:

"Each State Party to this Convention undertakes not to transfer to any recipient whatsoever, directly or indirectly, and not in any way to assist, encourage, or induce any State, group of States or international organisations to manufacture or otherwise acquire any of the agents, toxins, weapons, equipment or means of delivery specified in Article I of the Convention." (emphasis added)
So it has to be asked whether publication of the H5N1 studies would assist those with hostile intent in the acquisition of what is banned by Article I.

After careful deliberation and several hundreds of hours of discussion in late 2011 the NSABB reached the conclusion that these papers could not be published in full because of the risks of subsequent misuse. As one of the Board members commented on the recommendation, "We don't want to give bad guys a road map on how to make bad bugs really bad" [31]. However, this decision was then discussed by 21 influenza experts and one ethicist at an international meeting at the World Health Organisation (WHO) and that meeting had reservations about what the NSABB had decided [32]. So upon a request by the NIH the NSABB again considered the issue at another meeting that was addressed by the senior scientists of the two groups. Following an intensive two-day discussion the members of NSABB decided that the papers should be published in full. A crucial factor for this decision was the new policy for oversight of dual-use research of concern [33], which the US Government issued on the first day of the NSABB meeting and which allowed classification of scientific work on security grounds. So, in the absence of appropriate mechanisms for disseminating research findings on a need-to-know basis, the Board was left with the option of either stopping or allowing publication, and in such circumstances they opted for the latter. One member of the Board was quoted as saying [34]:

"...the group would likely have still recommended that the studies be redacted - published in abbreviated form - but the NSABB, as others, have concluded that the option is unworkable."

Even then, however, some members had deep concerns. The eighteen voting members of the Board were unanimously in favour of publication of the work carried out in the USA, but six voted against publication of the work done in The Netherlands. Similarly, the Dutch Government discussed whether the results of the work carried out there had created knowledge that might be too dangerous to export but eventually agreed to publication [35]. Meanwhile, one of the NSABB members recently voiced concerns about the way in which the second Board meeting (29-30 March 2012) had been organised. In a letter addressed to a senior NIH official, Professor Michael Osterholm stated that the meeting "was designed to produce the outcome that occurred" representing a very "one sided" picture of the riskbenefit of communicating the research results openly [36]. 
Specifically, he emphasises that "the Board received no formal or informal presentation from those on the front lines of $\mathrm{H} 5 \mathrm{~N} 1$ animal surveillance" and that the security briefing at which the risks of malevolent applications of the mutation data were discussed was "incomplete" and even "useless" [37].

Even though all of the NSABB deliberations took part behind 'closed doors' and were never given detailed media coverage, several Board members have commented on why they were opposed to the publication of the studies, especially the one conducted in the Netherlands. In their view, the main reason why the projects were problematic was that they fell into both the fourth and the fifth categories of research of concern listed by the Fink Committee. That is experiments that [38]:

"Would increase transmissibility of a pathogen..." "Would alter the host range of a pathogen..."

In addition, it can be argued that making deadly $\mathrm{H} 5 \mathrm{~N} 1$ influenza contagious would also come under the seventh of Fink's categories. That is an experiment that "Would enable the weaponisation of a biological agent or toxin". This follows because Article I.2 of the BTWC states [39] that the prohibition covers "Weapons, equipment or means of delivery designed to use such agents or toxins for hostile purposes or in armed conflict", whereby contagion though the air is clearly a means of delivery.

The reported views of knowledgeable members of the NSABB in the period after the WHO meeting and before the second decision of the NSABB are instructive in trying to understand why even in the constrained situation of the second meeting some people still voted against publication of the work of the group from The Netherlands. David Relman and Stanley Lemon co-chaired the follow-up report to that of Fink [40]. Relman was reported to have said [41]:

"My bottom line: Fouchier started with a highly worrisome and sometimes lethal virus to humans and appears to have enhanced its transmissibility by the respiratory route. Nothing said in recent days changes these facts..."

\section{And Lemon said bluntly [42]:}

"The major concern has been about acquisition of the capability for aerosol transmission of the virus to a mammal."

Now people who have looked at such experiments of concern in detail $[43,44]$, state that it will frequently be possible for an oversight system to suggest modifications at the project proposal stage that can avoid these kinds of difficulty later.

It is, however, difficult to see how Fouchier's experiment could have been so modified because of its stated objectives. It has to be reiterated that Fouchier has been open about the objective of the work throughout the recent public debate [45]:

"Our research program on $\mathrm{H} 5 \mathrm{~N} 1$ virus transmission, which led to submission of one of the papers that has stirred up so much recent controversy, aimed to investigate whether and how HPAI [Highly Pathogenic Avian Influenza] H5N1 virus can acquire the ability to be transmitted via aerosols among mammals and whether it would retain its virulence..."

Given the shambles amongst the scientific community it is hardly surprising that politicians have begun to step in on behalf of the wider society.

A senior US Congressman summarised the present disarray amongst life scientists with a series of questions to the White House science advisor. These questions well illustrate how little life scientists have been able to accomplish in protecting their work from hostile misuse over the last 10 years. The Congressman's questions were [46]:

1. "How does NSABB weigh the potential risks and benefits of dual-use research? When does it advocate against publication?

2. What systems exist to identify and, if necessary, control early stage dual-use research?

3. ....What is the government's current system for disseminating legitimate dual-use research worldwide? How is that system being implemented with respect to the articles in question?

4. Is the NIH's review system adequate to identify potentially dangerous dual-use research? Why did it fail to identify the avian flu research until it was completed and submitted for publication?"

These are very difficult questions and might lead to the conclusion that oversight really is unworkable. If that position is accepted, then there is little need for dual-use/biosecurity education of life scientists because either everything that can be done is allowed, or politicians will decide what can be done. This particular example of the creation of a contagious lethal H5N1 virus, and the difficulty of agreeing what should be done about it, should certainly give everyone pause for thought. Meanwhile, it is noteworthy that the team in the Netherlands has already "identified an addition mutation that results in ferret-to-ferret transmis- 
sion without the need for repeated passage of the virus in ferrets" [47]. However, we think oversight still has a role to play both in lessening difficulties by allowing modification of individual projects, but more fundamentally, in laying the foundations for a much wider understanding of the risks and the resultant responsibilities of life scientists.Above all, for research oversight to be effective, the life science community as a whole needs to be sensitised to the dangers posed by the potential misuse of life science knowledge and to how those can be mitigated. It is to such wider understanding, awareness-raising and education that should come out of the avian influenza debate that we now turn.

\section{The Wider Responsibilities of Life Scientists}

In contrast to the narrow view of the potential dangers enclosed in the dual-use/bioterrorism framework, for over two decades there has been a well-articulated view that what is needed to prevent the militarisation of the modern life sciences is an integrated "web of preventive policies" that will persuade anyone thinking of going down that path that the costs will far outweigh the benefits [48]. Furthermore, given that there were a series of offensive biological weapons programmes by major States in the last century $[49,50]$ it has to be understood that these policies have to be centred on the 1975 BTWC. The web of policies would, for example, include: controls;

- Effective intelligence; Co-ordinated export

- As strong as possible BTWC implemented in-depth nationally;

- Sensible biodefence against validated threats; and

- A clear international determination to respond vigorously to any violation of the norm embodied in the prohibition regime.

What is of interest here is the State Parties' understanding of in-depth implementation of the BTWC nationally.

Article IV of the BTWC requires that State Parties take measures to prohibit and prevent what is banned in Article I, and the meaning of 'prevent' clearly involves life scientists. At the Second Review Conference of the BTWC in 1986 State Parties agreed, in relation to Article IV, that [51]:

"The Conference notes the importance of: inclusion in textbooks and in medical, scientific and military educational programmes of information dealing with the prohibition of microbial or other biological agents or toxins and the provisions of the Geneva Protocol [of 1925]."
And similar statements have been repeated at subsequent Review Conferences. So there is no doubt that an aware and educated life science community worldwide is essential for the strength of the prohibition regime. Clearly, there is much that such an educated and engaged community could contribute to preventing the hostile misuse of their work. For example, Synthetic Biologists have investigated measures that could help to ensure that those with hostile intent cannot easily order dangerous material from commercial companies [52].

However, it is also abundantly clear that most practicing life scientists have little or no understanding of the Convention, or of their responsibilities under the Convention. As a major Working Paper by 12 State Parties, including the USA and the UK, for the Seventh Review Conference states [53]:

"Life scientists do not often consciously consider the possibility that their work could be of relevance to a biological weapons programme or other wise misused to cause harm to people, animals or plants or to render critical resources unusable...”

Unsurprisingly, therefore, State Parties considered what might be done to raise the awareness and education of life scientists in their annual meetings in 2005 and 2008 so that scientists could become better engaged, for example, in the development of codes of conduct and oversight systems.

Indeed, in 2008 State Parties agreed on the value of a series of educational measures that would include [54]:

i. "Explaining the risks associated with the potential misuse of the biological sciences and biotechnology;

ii. Covering the moral and ethical obligations incumbent on those using the biological sciences;

iii. Providing guidance on the types of activities which could be contrary to the aims of the Convention and relevant national laws and regulations and international law;

iv. Being supported by accessible teaching materials, train-the-trainer programmes, seminars, workshops, publications, audio-visual materials..."

In their 2011 Working Paper the 12 State Parties detailed what they had done in order to carry out such awareness-raising and educational activities [55]. Additionally, nongovernmental organisations have reported their efforts to develop and make available relevant teaching materials, train-the-trainer programmes, and seminars and workshops [56]. Yet it is obvious that a great deal more will have to be done in order to elaborate 
and implement comprehensive national strategies on education in biosecurity so that life scientists will be in a position to contribute their expertise to preventing the future militarisation of the life sciences.

In that context, it is hardly surprising that State Parties to the BTWC at the Seventh Review Conference agreed to have a Standing Agenda Item (SAI) for their meetings through to the next review on "Review of developments in the field of science and technology related to the Convention", and that two of the sub-items under this SAI would be [57]:

"(d) voluntary codes of conduct and other measures to encourage responsible conduct by scientists, academia and industry.

[and]

(e) education and awareness-raising about risks and benefits of life sciences and biotechnology."

Unfortunately, what is also evident is that, given the limited time available for the annual meetings at Expert and State Party levels, and the very crowded agenda, it is unlikely that State Parties will be able to make substantive and cumulative progress on these sub-topics before the Eighth Review Conference without considerable help from the scientific community in providing input to the meetings, and analyses of the outcomes, in 2012, 2013, 2014 and 2015.

Our view is that a comprehensive strategy on awareness-raising and education will have to be developed by each State Party and its implementation carefully monitored if significant progress is to be ensured [58]. However, if progress is well reported to the annual meetings of the BTWC, there is a hope that a rapid evolution of best practices will be possible. In that regard, our own experience strongly suggests that educational programmes need to begin by adding the issues of biosecurity and dual-use to the range of topics, such as plagiarism and fraud that scientist are increasingly made aware of and cautioned about in courses on the responsible conduct of research [59]. But we also consider that this basic awareness-raising has to be supplemented, whatever the problems of teaching such material to scientists [60], with some straightforward material on how philosophers deal with ethical questions [61]. It should then be possible for scientists to think more clearly about their responsibilities in relation to experiments that raise dual-use concerns. We have certainly found that scientists who have become aware of the potential dangers are very serious about their responsibilities in protecting the results of their work from misuse [62]. Nevertheless, as the H5N1 experiments of concern discussed here have demonstrated all too clearly, responsibility cannot be discharged solely at the level of the individual scientist's projects and publications. It is necessary that a wider framework of understanding is developed so that dual-use and bioterrorism are seen as only part of a much wider problem of protecting the life sciences from large scale militarisation. Then the much wider range of actions that can be taken will become available to the life science community as a whole. Of course, it is noteworthy that the challenge of dual-use is not unique to the life science, but arises in other fields of study, such as chemistry, as it has already been demonstrated [63].

\section{СОЗДАНИЕ КОНТАГИОЗНОГО ВИРУСА ГРИППА Н5N1: ЗНАЧЕНИЕ ДЛЯ ОБРАЗОВАНИЯ СПЕЦИАЛИСТОВ В ОБЛАСТИ НАУК О ЖИЗНИ}

\section{T. Новоссёлова, М. Минехата, М. Дандо}

Центр исследований по разоружению в Брэдфорде, Школа мировых исследований Университета социальных и международных исследований в Брэдфорде, Великобритания

Авторы статьи утверждают, что продолжающаяся дискуссия вокруг создания контагиозного вируса гриппа Н5N1 показала существование суровых ограничений для предотвращения злоупотреблений в области наук о жизни посредством надзора над планами и публикациями. Далее утверждается, что для того, чтобы избежать потенциальной тотальной милитаризации наук, связанных с жизнью, необходимо, чтобы ученые - специалисты в области естественных наук - осознавали свою ответственность в контексте Конвенции о биологическом и токсикологическом оружии (BTWC) и делали активный вклад в контроль над режимом нераспространения биологического оружия.

К л ю чевы е с лов а: H5N1, науки о жизни (естественные науки), надзор, образование, BTWC, биотерроризм. 


\section{СТВОРЕННЯ КОНТАГІОЗНОГО ВІРУСУ ГРИПУ Н5N1: ЗНАЧЕННЯ ДЛЯ ОСВІТИ СПЕЦІАЛІСТІВ У ГАЛУЗІ НАУК ПРО ЖИТТЯ}

\section{T. Новоссьолова, М. Мінехата, М. Дандо}

\section{Центр досліджень із роззброєння в Бредфорді, Школа світових досліджень Університету соціальних і міжнародних досліджень у Бредфорді, Велика Британія}

Автори статті стверджують, що триваюча дискусія навколо створення контагіозного вірусу грипу H5N1 показала існування суворих обмежень для запобігання зловживань в галузі наук про життя за допомогою нагляду над планами та публікаціями. Далі стверджується, що для того, щоб уникнути потенційної тотальної мілітаризації наук, пов'язаних із життям, необхідно, щоб вчені - фахівці в галузі природничих наук усвідомлювали свою відповідальність у контексті Конвенції про біологічну і токсикологічну зброю (ВTWC) i робили активний внесок у контроль над режимом нерозповсюдження біологічної зброї.

К л ючов і слова: H5N1, науки про життя (природничі науки), нагляд, освіта, BTWC, біотероризм.

1. WHO. [accessed 1/05/12] Cumulative Number of Confirmed Cases of Avian Influenza A(H5N1) Reported to WHO. 2012. Available at: http://www.who.int/influenza/human animal_interface/

2. Committee on Research Standards and Practices to Prevent the Destructive Application of Biotechnology. Biotechnology Research in an Age of Terrorism. National Academies Press; Washington, D.C.: 2004.

3. Meselson M. Averting the Hostile Exploitation of Biotechnology. The Chemical and Biological Weapons Conventions Bulletin. 48:16-19. (20000.

4. See reference 1 , page .

5. See reference 1 , page .

6. See reference 1 , page .

7. See reference 1, page .

8. Committee on Advances in Technology and the Prevention of their Application to Next Generation Biowarfare Threats. Globalization, Biosecurity, and the Future of the Life Sciences. National Academies Press; Washington, D.C.: 2006.

9. See reference 1, page .

10. Kennedy D. Better Never Than Late. Science. 2005; 310:195. [PubMed: 16223986]
11. Journal Editors and Authors Group. Uncensored Exchange of Scientific Results. PNAS. 2003; 100, 4:1464. [PubMed: 12590129]

12. Wellcome Trust. [accessed 1/05/12] Position Statement on Bioterrorism and Biomedical Research. SeeAvailable at: http://www. wellcome.ac.uk/About-us/Policy/Policy-andpositionstatements/WTD002767.htm

13. IAP. [accessed 1/05/12] Statement on Biosecurity. 2005. Available at: http://www. interacademies.net/File.aspx?id $=5401 \mathrm{~d}$

14. Biosecurity Working Group. A Code of Conduct for Biosecurity. Royal Netherlands Academy of Arts and Science; Amsterdam: 2007.

15. Enserink M. [accessed 26/04/12] Scientists Brace for Media Storm around Controversial Flu Studies. ScienceInsider. Nov 23. 2011 Available at: http://news.sciencemag.org/ scienceinsider/2011/11/scientists-brace-formedia-storm.html

16. Miller $N$. [accessed 26/04/12] Scientists Call for Curbs on Own Research on Deadly Bird Flu Virus. The Guardian. Feb 3. 2012 Available at: http://www.guardian.co.uk/world/2012/feb/03/ bird-flu-virus-scientists-warning

17. Roos R. [accessed 1/05/12] Live Debate Airs Major Divisions in H5N1 Research Battle. CIDRAP. Feb 3. 2012 Available at: http://www. cidrap.umn.edu/cidrap/content/influenza/ avianflu/news/feb0312webinar-jw.html

18. See reference 14 , page .

19. Wimmer E. The Test-Tube Synthesis of a Chemical Called Polio. EMBO Reports. 2006; 7:S3-S9. [PubMed: 16819446]

20. Vogel K. M. Framing Biosecurity: an alternative to the biotech model? Science and Public Policy. 2008; 35(1):45-54.

21. Young E. [accessed 1/05/12] The Risks and Benefits of Publishing Mutant Flu Studies. Nature: News: Explainer. Mar 7. 2012 Available at http://www.nature.com/news/therisks-and-benefitsof-publishing-mutant-flustudies -1.10138

22. [accessed 1/05/12] See Deliberating Over Danger. The Scientist. Apr 1. 2012 Available at: $\quad$ http://the-scientist.com/2012/04/01/ deliberating-over-danger/

23. Mackenzie D. [accessed 26/04/12] Five Easy Mutations to Make Bird Flu a Lethal Pandemic. The New Scientist. Sep 26. 2011 Available at: http://www.newscientist.com/ article/mg21128314.600-five-easy-mutationsto-make-bird-flu-a-lethal-pandemic.html

24. See reference 22.

25. Editorial. Facing up to Flu. Nature. 2012; 482:131. 
26. [accessed 1/05/12] For the full text of the BTWC. see www.opbw.org

27. Seventh Review Conference of the States Parties to the Convention on the Prohibition of the Development. Production and Stockpiling of Bacteriological (Biological) and Toxin Weapons and on their Destruction. Final Document, BWC/CONF. Vol. VII/7. United Nations; Geneva: 2012. p. 10

28. Herfst $S$. et al. The Future of Research and Publication on Altered H5N1 Viruses [advanced version]. Journal of Infectious Diseases. Mar 27.2012

29. Kawaoka $Y$. Transmission of an Influenza Virus Possession H5 hemmagglutinin via respiratory Droplets in Ferrets; Presentation given at International Symposium H5N1 Research: Biosafety, Biosecurity and Bioethics; London: The Royal Society; Apr 3-4. 2012

30. See reference 26.

31. See reference 15.

32. Vogel G. [accessed 1/05/12] Flu Experts and One Ethicist - Debate Controversial H5N1 Papers. ScienceInsider. Feb 16. 2012 Available at: http://news.sciencemag.org/ scienceinsider/2012/02/flu-expertsand-oneethicist.html

33. United States. [accessed 1/05/12] United States Government Policy for Oversight of Life Sciences Dual Use Research of Concern. 2012. Available at: http://oba.od.nih.gov/oba/ biosecurity/pdf/united_states_government_ policy_for_oversight_of_durc_final_ version_032812.pdf

34. Branswell H. US Biosecurity Panel Clears Publication Path for Controversial Bird Flu Studies. The Canadian Press; Mar 30. 2012 Available at: http://www.cbc.ca/news/ technology/story/2012/03/30/bird-flu-studiespublication.html

35. Enserink M. Will Dutch Allow 'Export' of the Controversial Flu Study. Science. Apr 20.2012 336:285. [PubMed: 22517831] See also Enserink, M. [accessed 1/05/12] Dutch Government OK's Publication of H5N1 Study. ScienceInsider. Apr 27. 2012 Available at: http:// news.sciencemag.org/scienceinsider/2012/04/ dutch-government-oks-publication.html

36. Maher B. [accessed 1/05/12] Bias Accusation Rattles US Biosecurity Board. Nature News. Apr 14. 2012 Available at: http://www. nature.com/news/bias-accusation-rattles-usbiosecurity-board-1.10454

37. Ibid. See Letter from Michael Osterholm to Amy Patterson (NIH).

38. Cohen J., Malakoff D. [accessed 1/05/12] NSABB Members React to Request for Second
Look at H5N1 Flu Studies. ScienceInsider. Mar 2. 2012 Available at: http://news.sciencemag. org/scienceinsider/2012/03/nsabb-membersreact-to-request.html

39. See reference 26.

40. See reference 7.

41. See reference 38 .

42. Ibid.

43. Steinbruner J. et al. Controlling Dangerous Pathogens: A Prototype Protective Oversight System. CISS, University of Maryland; 2007. See

44. Rath J. Mutant Flu: Assessing Biosecurity Risks. Nature. Feb 23.2012 482:470. [PubMed: 22358821]

45. Fouchier R. A. M. et al. Restricted Data on Influenza H5N1 Virus Transmission. Science. Feb 10.2012 335:662-663. [PubMed: 22267582]

46. Malakoff D. [accessed 1/05/12] Senior U.S. Lawmaker Leaps into H5N1 Flu Controversy. SeniorInsider. Mar 4. 2012 Available at: http:// news.sciencemag.org/scienceinsider/2012/03/ senior-us-lawmaker-leaps-into-h5.html

47. See reference 36 .

48. Pearson G. Prospects for Chemical and Biological Arms Control: The Web of Deterrence. Washington Quarterly. 1993; 16, 2:145-162.

49. Geissler E., van Courtland Moon J. E., editors. Biological and Toxin Weapons: Research, Development and Use from the Middle Ages to 1945. Oxford University Press; Oxford: 1999.

50. Wheelis M., Rozsa L., Dando M. Deadly Cultures: Biological Weapons since 1945. Harvard University Press; Cambridge MA: 2006.

51. [accessed 1/05/12] For full texts of the outcomes of BTWC Review Conferences. see www. opbw.org

52. Garfinkel M. et al. Synthetic Genomics: Options for Governance. J Craig Venter Institute, CSIS, MIT; 2007.

53. Australia. et al. Possible approaches to education and awareness-raising among life scientists. BWC/CONF.VII/WP20/ Rev.1. United Nations; Geneva: 2011.

54. Report of the Meeting of State Parties to the Biological and Toxin Weapons Convention. BWC/ MSP/2008/5. United Nations; Geneva: Dec. 2008.

55. See the Annex to reference 52.

56. See, for example, Minehata M. et al. [accessed 2/05/12] Implementing Biosecurity Education: Approaches, Resources and Programmes [online version]. Science and Engineering Ethics. Nov 8. 2011 Available at: http://www. springerlink.com/content/j6137g35567j7731/ 
57. See reference 27 , page.

58. See NSABB. [accessed 1/05/12] Strategic Plan for Outreach and Education on Dual Use Research Issues. 2008. Available at: http:// oba.od.nih.gov/biosecurity/biosecurity documents.html

59. Committee on Science. Engineering and Public Policy. On Being a Scientist: A Guide to Responsible Conduct of Research. 3rd ed. National Academes Press; Washington DC: 2009.

60. Johnson J. Teaching Ethics to Science Students: Challenges and a Strategy. In: Rappert, B., editor. Education and Ethics in the Life
Sciences. Australian National University E Press; 2011.

61. Huff C., Frey $W$. Moral Pedagogy and Practical Ethics. Science and Engineering Ethics. 2005; 11:389-408. [PubMed: 16190280]

62. Whitby $S$. Strengthening the Biological Weapons Convention: Preserving Academic and Scientific Freedom [online]. Science, People and Politics. 2012; 3:2.

63. See Dando M. Help or Harm? [online]. Chemistry World. 2012; 9:5. Available at: http://www.rsc. org/chemistryworld/Issues/2012/May/helpor-harm.asp. 